Fig.1C

Serum Samples

\title{
AECOPD $\left(\mathrm{PaO}_{2}, \mathrm{mmHg}\right)$
}
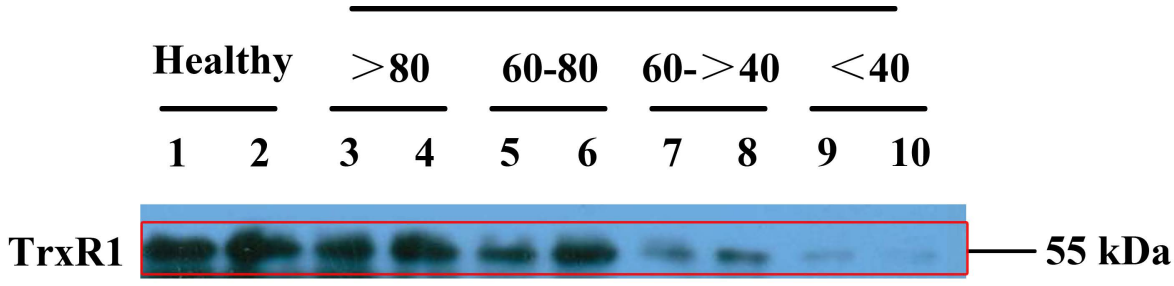

Trx1

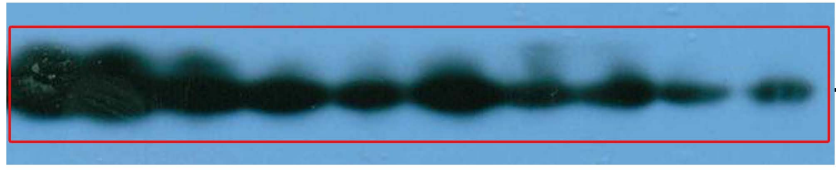

-12 kDa

Fig.1E

Serum Samples

\section{AECOPD $\left(\mathrm{PaO}_{2}, \mathrm{mmHg}\right)$}

Marker

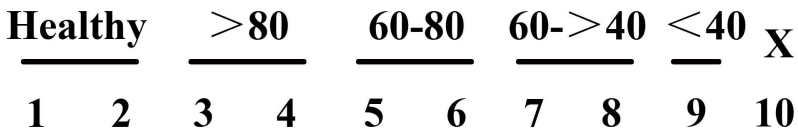

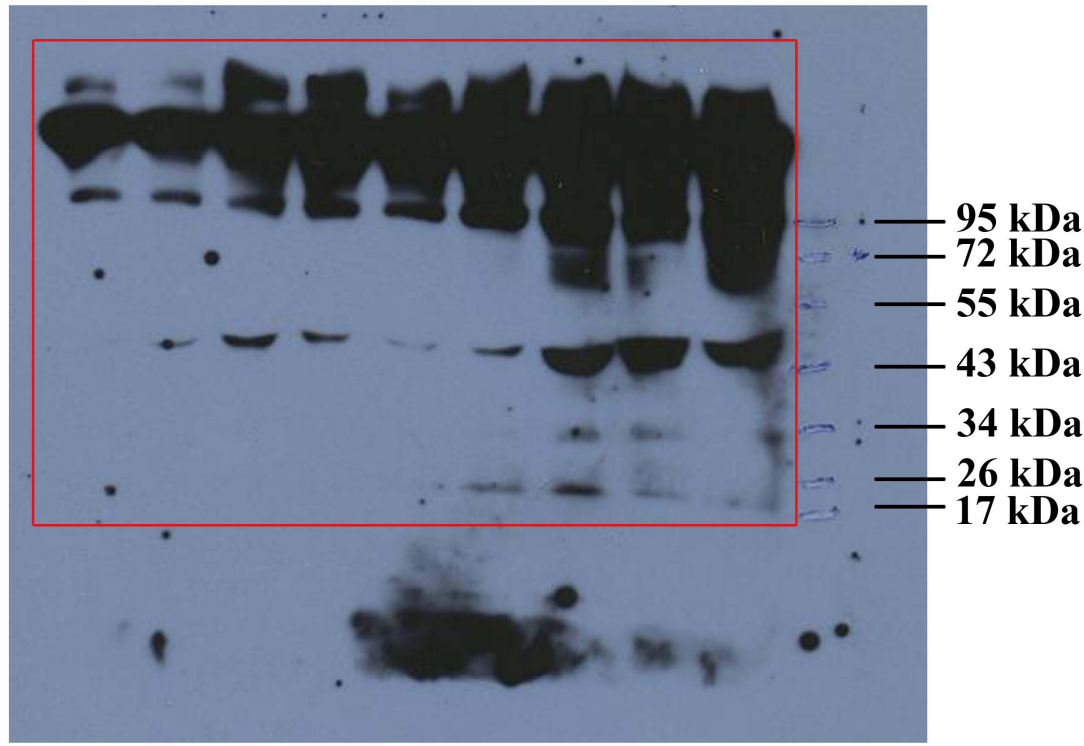


Fig.2A

Serum Samples of AECOPD

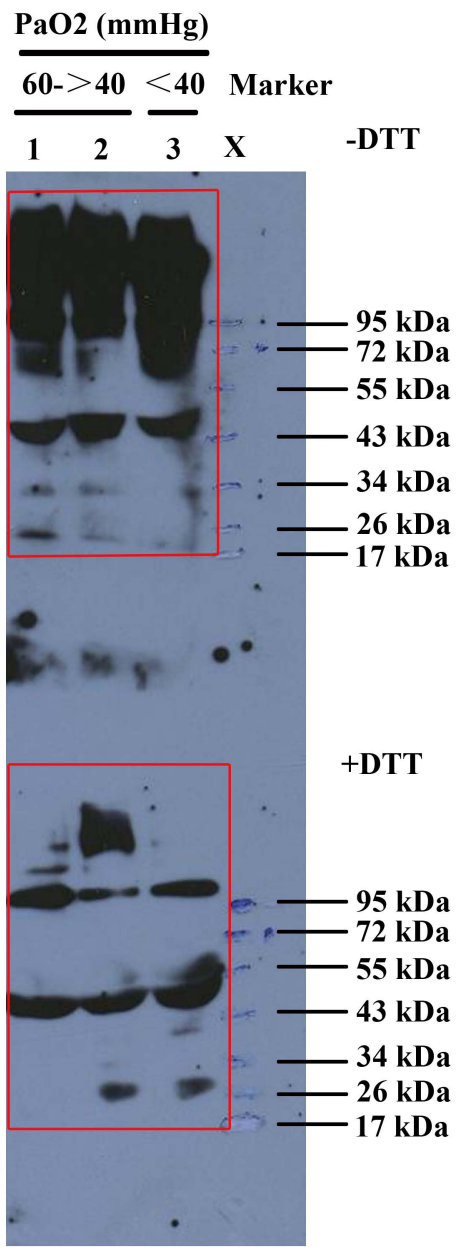

Fig.2B

Serum Samples of AECOPD

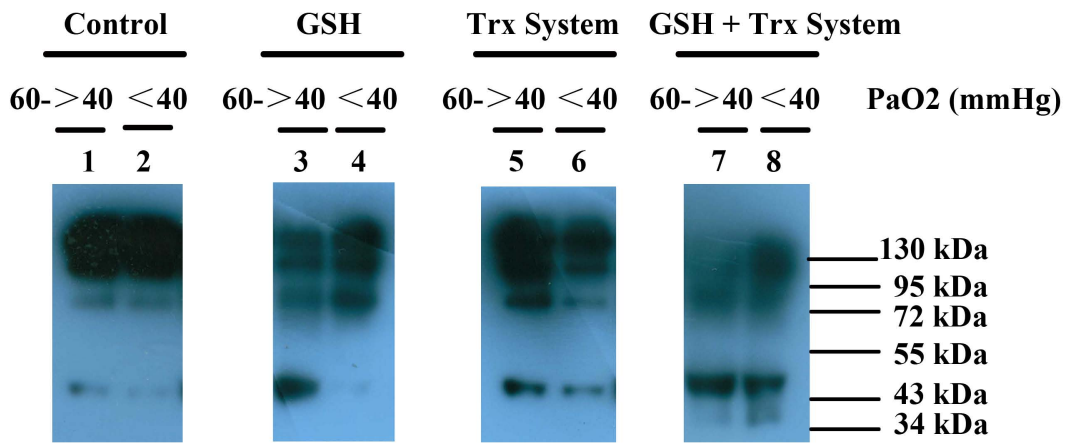

Fig.2C

Serum Samples of AECOPD and Health
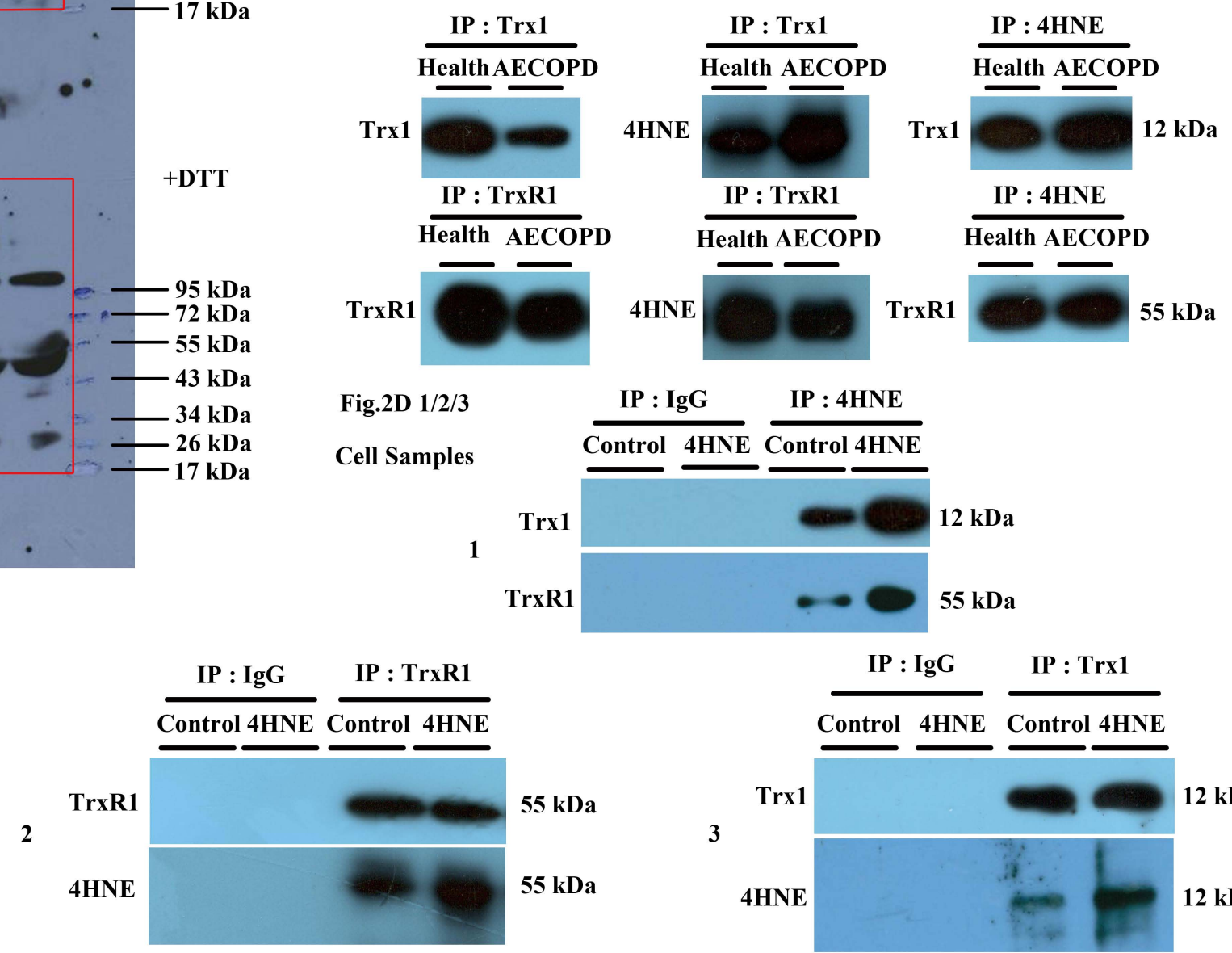

55 kDa

55 kDa

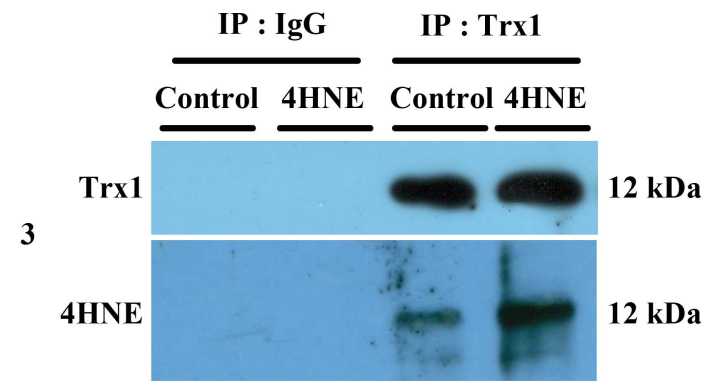


Fig. 3E

Cell Samples

4HNE $(\mu M)$

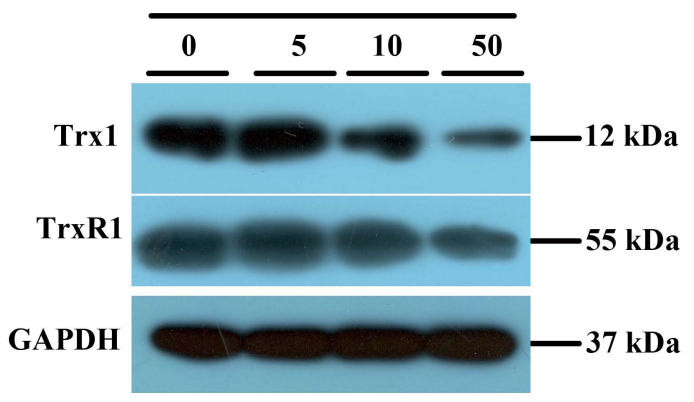

Fig. 3G

Cell Samples

4HNE ( $\mu M)$

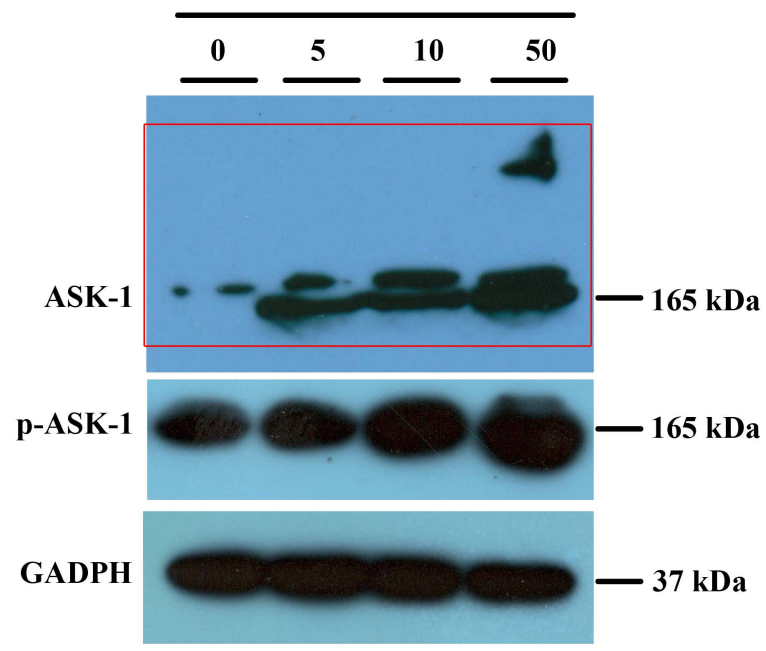

Fig. 3F

Cell Samples

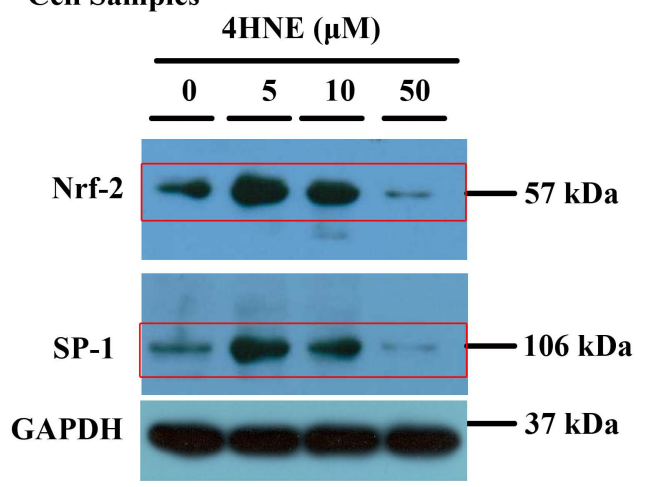

Fig. 5A

Cell Samples

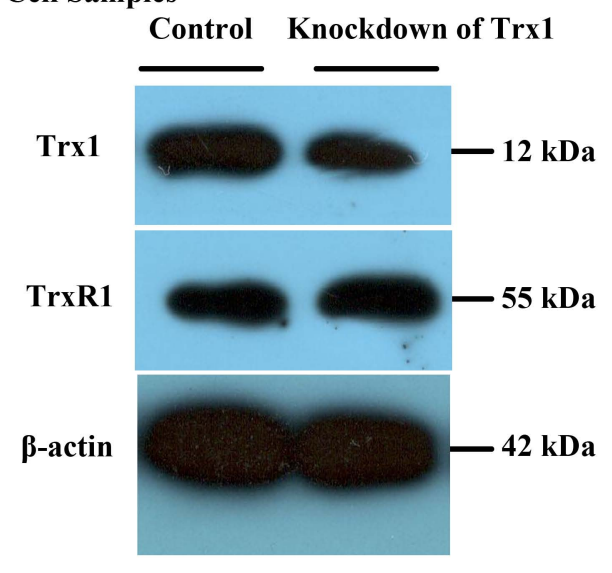

